assertion of women's rights on campus would begin, culminating in the completion of co-education at University College between 1940 and 1959.

Steps might have been taken as early as 1914 to deal with the recurring problems of residence authority, sorority power, and moral decline. Instead, because of distractions caused by the war effort, and President Falconer and others' insistence that men not on campus took priority over women on the campus, Phyllis Grierson went mad, Margaret Ross was expelled, and the Queen's Hall girls poisoned relations between conflicting women's groups on campus for nearly a decade. That none of it was prevented is testimony to the continued second-class status of women at the University of Toronto even some thirty years after co-education was introduced. 


\section{Phyllis Grierson, Margaret Ross, and the Queen's Hall Girls: Intergroup Conflict Among University College Women 1910-21}

\section{Charles Levi}

In fall 1946 and spring 1947, University of Toronto President Sidney Smith received 52 rambling pages from one Phyllis Grierson, a graduate of University College in 1917 and for the previous thirty years a teacher in Edmonton and Victoria. In 1941 Grierson had declared she wished to sever her connection with the University. Only now did she explain why:

It is my hope that in this life I may never again live and work in an atmosphere of such legally organized social selfishness and such ill-mannered rudeness as that in which I lived as an undergraduate of University College, Toronto. ${ }^{1}$

In the pages that followed Grierson drew parallels between the Nazi regime just defeated in Europe and the undergraduate social organizations of the University of Toronto during the Great War. As she put it, "The Fraternity and Sorority Nazi-Fascist system might well be termed a Hitler Youth Movement," asking rhetorically, "If a secret society is not an underhand, underworld combine, what is it?"3

The present university governments... have farmed out the real government of those institutions to the international, underhand [sic], indirect, bureaucratic, family-compact social-caste governments of the exploiting fraternity and sorority gangster combines... legalized into seeming respectability by irresponsible government, camouflaged by Greek letters. ${ }^{4}$

In a subsequent document she characterized these "gangsters" more precisely: social models, interferers, irresponsible underworld judges, exploiters, backwhisperers and gossips, subjectors, enslavers, and irresponsible governors of the students of those institutions. ${ }^{5}$

Smith made no reply, choosing to accept counsel from Principal Taylor of University College that Grierson had been a poor student unable "to meet the standards of the curriculum," and that she was "on the border of some psychiatric condition." "But understood in connection with the history of the female population of University College from 1910-1921, Grierson's comments are less the ramblings of a madwoman than an accurate, if emotional assessment of the state of the College.

'Grierson to Smith, 9 October 1946, University of Toronto Archives (UTA)/Office of The President(Smith)/A68-0007/17(10).

${ }^{2}$ Grierson large document, Ibid., 22.

${ }^{3}$ Ibid., 8.

${ }^{4}$ Ibid., $1,4$.

${ }^{5}$ Grierson smaller document, University of Toronto Archives (UTA)/Office of The President(Smith)/A68-0007/17(10), 1.

${ }^{6}$ W.R. Taylor to Smith, 9 November 1946, University of Toronto Archives (UTA)/Office of The President(Smith)/A68-0007/17(10).

(C) Historical Studies in Education/Revue d'bistoire de l'éducation 12, nos. 1/2 (2000): 73-92. 
Under wartime pressure, the University of Toronto abrogated responsibility for the condition of women on the campus, concentrating instead on cajoling the remaining men to do their part overseas, and supporting their efforts once they got there. By the time the war ended the situation had spiralled out of control, and drastic steps had to be taken to restore order among College women. In doing so, the University carried on a tradition of marginalizing women on campus.

The literature on women at the University of Toronto has greatly expanded in recent years. Sara Burke has described how the creation of social service at the University of Toronto "allowed the reform interests of men and women to be both segregated and placed in contention," and how women cultivated "their own independent interest in social service. "7 The prevalence of women in social service "implicitly challenged the gendered assumptions" emanating from a Department of Political Economy run by men. ${ }^{8}$ Burke noted a 1909 scheme to move women off campus and into a separate college, and otherwise to segregate space on campus to avoid excessive contact between male and female undergraduates.'

Segregation, as Alyson King has pointed out, was a main factor behind the creation of women's residences. These buildings would provide a home-like atmosphere and keep women from proximity to men on campus and to undesirables in the city. ${ }^{10}$ The equation of residence and family life was meant to have an elevating effect on the female undergraduate, but "reinforced patriarchal assumptions that women students needed more protection and supervision than their male counterparts." 11

The relegation of women to the margins was hardly peculiar to the University of Toronto, universities in Canada, or indeed to Canada itself. Sir Robert Falconer, President of the University of Toronto during the period under study here, saw his institution as a member of an imperial network of universities. ${ }^{12}$ The "marginality" of women is unsurprising, considering educational practice across the Empire.

The primary "occupation" of women in the British Empire was that of wife and mother, generally viewed as incompatible with any other work. Most women who worked did so in domestic service. ${ }^{13}$ For an educated woman who did not

'Sara Burke, Seeking the Highest Good: Social Service and Gender at the University of Toronto 1888-1937 (Toronto: University of Toronto Press, 1996), 7.

${ }^{8}$ Ibid., 42.

95ara Burke, "A Separate College for Women: Controversy over Co-education at the University of Toronto, 1909-1919" (CHA Paper, 1999).

${ }^{10}$ Alyson King, "Centres of Home-Like Influence: Residences for Women at the University of Toronto," Material History Review 49 (Spring 1999): 44-5, 47.

"Ibid., 56.

12James G. Greenlee, Sir Robert Falconer: A Biography (Toronto: University of Toronto Press, 1988), 179-89.

${ }^{13}$ Sue Bruley, Women in Britain Since 1900 (New York: St. Martin's Press, 1999), 19, 62-4; Lesley A. Hall, "Chloe, Olivia, Isabel, Letitia, Harriette, Honor, and Many More: Women in Medicine and Biomedical Science, 1914-1945," in Sybil Oldfield, ed., This Working-Day World: Women's Lives and Culture(s) in Britain 1914-1945 (London: Taylor \& Francis, 1994), 193-5; Alison Prentice et. al., Canadian Women: A History (Toronto: Harcourt Brace Jovanovich, 1988), 123, 139. 
marry, teaching at the elementary or secondary school level was nearly the only occupational choice. Some inroads had been made into such professions as law, medicine, and university teaching, but few women overcame the serious hurdles to launch careers. ${ }^{14}$ The Great War opened new professions for women, nursing and occupational therapy among them, but these had hardly gained respect by $1921 .{ }^{15}$ Veronica Strong-Boag has identified the main female professions as "nursing, teaching, social work, home economics, and library science;" recent scholarship has not lengthened the list. ${ }^{16}$

Outside the professions, women made little headway in either Canada or the empire. Those hired into the civil service in Canada by the end of the First World War faced limitations on the type and power of their appointments by $1918 .^{17}$ Nor had women achieved a place in the political mainstream. Although eligible for local office in Great Britain, British Columbia, and Ontario before the First World War, women had won few places. ${ }^{18}$ The great struggles for "votes for women" culminated in success in Canada, Great Britain, Australia, and New Zealand before and during the Great War. ${ }^{19}$ By 1921 , women could vote in many places, had won political offices, and achieved success in social reform, but there was a long way to go before suffrage led to substantive improvements in their lives and careers. ${ }^{20}$

As an educational institution in the British Empire, The University of Toronto was committed to the preservation of moral order and social utility. A pre-War "tango crisis" prompted public discussions about "improper" dancing, leading in turn to worry about social propriety. University authorities, under pressure from outside opinion, were forced to scrutinize student activities and their moral implications. ${ }^{21}$ Under normal conditions it was difficult enough for the University to enforce standards of morality and order upon an often-restive

${ }^{14}$ Bruley, Women in Britain, 20, 68; Prentice et. al., Canadian Women, 129-34.

${ }^{15}$ Meryn Stuart, "War and Peace: Professional Identities and Nurses' Training 1914-1930," in Elizabeth Smyth et. al., Challenging Professions: Historical and Contemporary Perspectives on Women's Professional Work (University of Toronto Press, 1999), 172-3, 183-6; Bruley, Women in Britain, 43-5.

${ }^{16}$ Veronica Strong-Boag, The New Day Recalled: Lives of Girls and Women in English Canada 1919-1939, (Mississauga, Copp Clark Pittman Ltd., 1988), 53. For discussion of some other professions, see Smyth et. al., Challenging Professions, op. cit.

17].E. Hodgetts et. al., The Biography of an Institution: The Civil Service Commission of Canada 1908-1967 (Montréal: McGill-Queen's University Press, 1972), 483-6; Strong-Boag, New Day Recalled, 62.

${ }^{18}$ Bruley, Women in Britain, 24-5; Prentice et. al., Canadian Women, 175-9.

${ }^{19}$ Bruley, op. cit., 46-51; Prentice et. al., op. cit., 207-09; Judith Aitken, "Women in the Political Life of New Zealand," in Phillida Bunkle and Beryl Hughes, ed., Women in New Zealand Society (Auckland, George Allen \& Unwin Australia Pty. Ltd., 1980), 11-13; Helen Jones, In Her Own Name: A History of Women in South Australia from 1836 (Kent Town, South Australia: Wakefield Press, revised edition, 1994), 157-67, 355-6.

${ }^{20}$ Prentice et. al., op. cit., 169-74.

${ }^{21}$ A.B. McKillop, Matters of Mind: The University in Ontario 1791-1951 (University of Toronto Press, 1944), 251-2. 
student body. Monitoring of activities became even more strained when attention fell on a "great cause" such as the war. This added to continuing worries about the safety of young women, especially in cities where (as Carolyn Strange has pointed out in Toronto's Girl Problem, ) fears of moral decline, "white slavery," and prostitution were paramount. ${ }^{22}$ Nationally, the YWCA was busy finding proper homes for "respectable girls" ${ }^{23}$ and anxious that the campus, no less than the city, harboured dangerous temptations for women students. ${ }^{24}$ Barry Moody remarks that in the Great War even such small universities as Acadia were dogged by the suspicion that the morals of students-especially women students - were slipping to dangerous lows. ${ }^{25}$ Similarly, John Reid writes that women at Mount Allison were prohibited for the duration of the War from visiting areas inhabited by soldiers. ${ }^{26}$

President Robert Falconer of the University of Toronto may have been aware of these issues, but his attitudes toward the women attending his University were not well-developed in the period surrounding the First World War. His biographer James Greenlee imagines him "like Mr. Chips, filtering through empty corridors while conjuring up the half-forgotten faces of his departed charges,"27 and quotes a letter to William Peterson remarking on "a great feeling of loneliness about this University. ${ }^{328}$ In fact the corridors were far from empty, and wartime was a period of great campus undergraduate activity. But it was women who filled the halls and crowded activities. ${ }^{29}$ Falconer was unaware of their collective presence.

In 1914 the University was only five years away from a Senate report arguing for effective segregation of women. The construction of Hart House and the Lillian Massey Treble building would further encourage it. ${ }^{30}$ The war exacerbated the sense of separation. In 1917, when R.W. Leonard suggested the University be closed during the War, he at any rate noticed the existence of campus women:

It is a pity that the University should close its doors to the lady students... but could they not make munitions, and would not such an action be very impressive and be a very valuable education to the generation now growing up?

\footnotetext{
${ }^{22}$ Carolyn Strange, Toronto's Girl Problem: The Perils and Pleasures of the City, 1880-1930.

${ }^{23}$ Wendy L.Mitchinson, "Aspects of Reform: Four Women's Organizations in Nineteenth Century Canada," Ph.D. Thesis, York University, 1976, 129-32.

${ }^{24}$ Diana Pedersen, "The Call to Service: The YWCA and the Canadian College Woman, 1885-1920," in Paul Axelrod and John G. Reid, eds., Youth, University, and Canadian Society (Montréal: McGill-Queen's University Press, 1989), 191.

${ }^{25}$ Barry M. Moody, "Acadia and the Great War," in Axelrod and Reid, op. cit., 155-6.

${ }^{26} \mathrm{John}$ G. Reid, Mount Allison University 1914-1963 (University of Toronto Press, 1984), 6.

${ }^{27}$ Greenlee, Sir Robert Falconer, 222.

${ }^{28}$ Ibid.

${ }^{29}$ Women made up $40 \%$ of the student body in $1915 / 16$ ( 374 of 914$), 53 \%$ in $1916 / 17$ (363 of 690 ) and $58 \%$ in $1917 / 18$ (376 of 650$)$, and $54 \%$ in 1918/19 (400 of 740). In 1919/1920 the figure had returned to $43 \%$ (451 of 1047). See generally, University of Toronto President's Reports, 1915/16-1919/1920.

${ }^{30}$ See Burke, "A Separate College for Women."
} 
Falconer replied that the few men remaining "will serve their country in the future by being good teachers or engineers or medical men." As for the women: "Only a small proportion would be accepted for munition work. Many of them would be physically unable for it." No mention was made of the possible contributions these women might make in later life, and Falconer's main argument against shutting down was that "to close the University would be to still one of the most helpful voices of the country."

Documents in the University of Toronto Archives and the pages of the Varsity show how marginality and morality played out at University College from the period between the defeat of a college for women proposal in 1909 to the end of the War. A proposal to remove women entirely from campus was defeated, and they entered a period in which they would, through sheer force of numbers, become the dominant group on campus. The period 1920-21 offered an opportunity to entranch the position of women on campus and to bring in coeducation. Although some women on campus noticed that this door had opened, the vast majority were too preoccupied with personal and group conflicts to step through it before it closed in the 1920s, not to re-open until after World War II. Intergroup conflict among University College women, against the backdrop of the "girl problem," the crisis over morals, and the disruptions of the First World War, show how the mechanics of co-education depended on the cohesiveness of university women as a group.

How, then, were women were organized at University College? The emphasis here must be on extracurricular activities, because women clustered around the Modern Languages and English courses.Inside the classroom, then, they shared similar experiences.

Outside the classroom, the picture was more complicated. As of 1910, University College had one main women's organization, the University College Women's Literary Society (WLS). The WLS had been founded in 1892 after women had failed repeatedly to gain admittance to the male University College Literary and Scientific Society. Like Levana at Queen's, ${ }^{32}$ the Delta Sigma Society at McGill, ${ }^{33}$ and Wauneita at the University of Alberta, ${ }^{34}$ the WLS operated on the principle of the "separate sphere." It was a "social and intellectual" organization ${ }^{35}$

\footnotetext{
${ }^{31}$ Leonard to Falconer, 6 January 1917 and Falconer to Leonard, 8 January 1917, UTA/ Office of the President (Falconer)/A67-0007/43.

${ }^{32}$ Levana was founded at Queen's in 1890 . Women could not vote in elections for the Queen's Alma Mater Society until 1917. See McKillop, Matters of Mind, 145-6.

${ }^{33}$ Delta Sigma was founded at McGill in 1885. Women were not allowed to join the McGill Students' Society until 1932. See Margaret Gillett, We Walked Very Warily: A History of Women at McGill (Montréal: Eden Press, 1991), 99-100, 237.

${ }^{34}$ Wauneita was founded in 1911 as a continuation of an earlier society formed in 1909 . It appears that women were not excluded from the University of Alberta Students' Council. See Laurie Mook, "Women at University: The Early Years," Alberta History (Winter 1996): 9-11.

${ }^{35}$ Varsity, 26 January 1892.
} 
aiming to "promot [e] literary work... and encourag [e] public speaking. ${ }^{.36}$ By 1911, it was holding regular meetings on the style of the Canadian parliament, defeating mock "bills" for the establishment of a separate college for women, and to provide for the establishment of household science as a compulsory course. ${ }^{37}$ Membership in the WLS was open to all members of University College on payment of a $\$ 1.00$ fee, and, at its height in 1911 boasted the membership of $54 \%$ of all women at University College. ${ }^{38}$

In 1914, reports of another organization began to appear in the student press. Known eventually as the Women's Undergraduate Association (WUA), it was not founded by a meeting of students, but was created by University College as an administrative rather than a literary organization. ${ }^{39}$ One of its first stated goals was to develop a system "for regulating the number of offices that may be held by any one person" at University College. ${ }^{\text {to }}$

Creation of the WUA sapped the membership of the WLS. By 1920, even after dropping fees to 50 cents, the WLS claimed the membership of only $13 \%$ of U.C. Women. ${ }^{41}$ Although the WUA would not seek a compulsory fee for all students of University College until $1917,{ }^{42}$ the divisive impact of the new organization was detected, and derided, by a recent alumna of the college as early as 1915 . When apprised that efforts were being made to abolish the WLS, this alumna declared that the WUA had "wrested only the prestige of authority" from the WLS, and that

the would-be Abolitionists may have known little intimacy with either association. It were [sic] surely a work of supererogation to compile a list of advantages to be derived from a Literary Society. ${ }^{43}$

The WLS carried on until the 1930 s as a subsidiary body of the WUA.

Apart from the WLS/WUA was another set of organizations dedicated to the social and intellectual development of women: the international Greek-letter sororities. These had been growing in the United States since 1870 , but until 1920 had Canadian counterparts only at the University of Toronto. ${ }^{44}$ The first, Kappa Alpha Theta, was founded in 1887, but collapsed two years later. It was

${ }^{36}$ Varsity, 18 December 1895.

${ }^{37}$ Varsity, 25 October 1911 and 24 November 1913.

${ }^{38}$ UTA/University College/WLS Roll Book of the Treasurer 1908-1929/A69-0011/20, as compared to enrollment of women at U.C. stated in President's Reports of the University of Toronto.

${ }^{39}$ The actual circumstances of its founding remain murky.

${ }^{40}$ Varsity, 13 November 1914.

${ }^{41}$ UTA/University College/wLS Roll Book of the Treasurer 1908-1929/A69-0011/20, as compared to enrollment of women at U.C. stated in President's Reports of the University of Toronto.

${ }^{12}$ Varsity, 9 February 1917.

${ }^{43}$ J.B.R. to Editor, Varsity, 15 December 1915. This was probably Jessie B. Reade, a U.C. graduate of 1915.

${ }^{44}$ Hellmuth Women's College in London did establish a branch of Chi Omega in 1899, but it disbanded in 1900, see James T. Brown, ed., Baird's Manual of American College Fraternities, 10th Edition (New York: James T. Brown, 1923), 415. 
refounded in 1905, followed by Alpha Phi (1906), Pi Beta Phi (1908), Kappa Kappa Gamma (1911), Delta Gamma (1913), Alpha Gamma Delta (1919), and Gamma Phi Beta (1919). ${ }^{45}$ All with the exception of Kappa Kappa Gamma were before 1920 based at University College. ${ }^{46}$

At face value the purposes of these sororities differed little from those of the WLS. They brought women together in rooms rented for the purpose, and dedicated themselves to high scholarship and friendly co-operation among their members. But they differed from the WLS, and later the WUA, in one important respect. The WLS and the WUA were open to all students at University College, without restriction. Sororities, through the annual process of "rushing," selected their members carefully from among the student body. They operated largely in secret, apart from the general atmosphere of College life, and this led to a degree of anti-sorority sentiment in segments of the student body.

Sororities did attempt to fit into the general stream of student life at the College. The official history of Alpha Phi emphasizes its support for "all college organizations," adding "Membership was encouraged in all executive and athletic clubs" and that the chapter always endeavoured "to make college interests stand first... in order to counteract the strong antifraternity feeling which still persists in University College."

Student yearsbooks from 1915 to 1919 show that between 1915-1916 and 1918-19, either the WUA or the WLS had a majority of Sorority members. In 1915-16, 1917-18, and 1918-19 it was the WUA, and in 1915-16 and 1916-17 the WLS. The height of Sorority power came in 1915-1916, when 13 of the 21 members of the WLS and WUA combined were from Sororities, although in 1916-17 the combined figure fell to 9 of $18 .{ }^{48}$ Sororities, in short, wielded power far beyond their actual numbers on campus.

Phyllis Grierson's complaints about sororities could not have come as much of a surprise to President Falconer. Approached in 1910 by a representative of an unnamed sorority that assumed there was "abundant room" for another on campus, he replied:

There are already within the University of Toronto three sororities. I do not feel disposed to favour the incoming of another Sorority, as while they may be of

${ }^{45} J o h n$ Robson, ed., Baird's Manual of American College Fratemities, 18th Edition (Menasha, Wisconsin: George Banta Company Inc., 1968), 212. Torontonensis often has different listings to Baird's manual. Three short-lived local sororities, Zeta Tau (1906-08), Sigma Beta Phi (1910-13), and Beta Delta Pi (1916-19) were never affiliated with an international group.

${ }^{46} \mathrm{Kappa}$ Kappa Gamma was located at the University of Victoria College until 1925, when it moved to University College, see Florence Burton-Roth and May Whiting-Westerman, The History of Kappa Kappa Gamma Fratemity 1870-1930 (Published by the Fraternity, 1932), 432-6.

${ }^{47}$ The History of Alpha Pbi International Fraternity 1872-1930 (New York: The Century Co., 1931), 243.

${ }^{48}$ Torontonensis, 1916, 1917, 1918, 1919. 
some advantage in some respects, they have caused some difficulties which I do not wish to do anything in the way of multiplying. ${ }^{49}$

Falconer's diffidence increased during the war. He replied to a request for "the best local sorority," "It would be impossible for me to undertake to differentiate between Sororities in the University of Toronto." Sent another letter asking for "any local in your university or of some women interested in sorority work," he passed the matter on to his secretary, who bluntly listed the names of the four sororities then on campus. ${ }^{50} \mathrm{By} 1915$, Falconer actively discouraged inquiries about sororities through his office.

By contrast, Falconer took a positive view of fraternities. In April 1915 he wrote to President Tory of the University of Alberta:

I must say that as far as my experience goes here I cannot see any injurious results from them in the way of discipline... I have a class on Sunday afternoons in the Fraternity House, changing the house every year. The men whom I meet are a very fine lot of fellows. I can see that Fraternities have served a good purpose, though they must be watched."

When Falconer received an anxious letter from an alumnus in 1916 asking for confirmation of rumours the University was going to use the War as a pretext to abolish fraternities, Falconer replied, "The suggestion of such a policy has never even been considered by me." 52 Falconer was kept informed of fraternity men who served with distinction at the front. ${ }^{53}$ Fraternities, then, were composed of upstanding and loyal men who could be preached to and could be expected to serve when needed. Whatever sororities might be composed of, Falconer had no use for them.

Beyond the divisions inherent in the WUA's supplanting of the WLS, and the potential divisive influence of sororities, the women at University College had another factor to deal with. Since 1905, when Queen's Hall was founded, some women lived in residence on campus and others did not. Although Queen's Hall social facilities were far from perfect, they were far superior to any that nonresidents could find in boarding houses.

Queen's Hall, under the nominal control of the Dean, Mrs. John Campbell, ${ }^{54}$ had established early on a tradition of Student self-government. ${ }^{55}$ Under the

${ }^{49}$ Miriam Alexander to Falconer, 2 May 1910; Falconer to Alexander, 17 May 1910, UTA/Office of the President (Falconer)/A67-0007/009.

${ }^{50}$ Mary Holt to Falconer, 22 February 1915; Falconer to Holt, 26 February 1915; Holt to Falconer, 1 March 1915; Annie Patterson to Holt, 8 March 1915, UTA/Office of the President (Falconer)/A67-0007/034.

${ }^{51}$ Falconer to Tory, 6 April 1915, UTA/Office of the President (Falconer)/A67-0007/036. Falconer had written a similar letter to President Mackenzie of Dalhousie on 6 March 1915, UTA/Office of the President (Falconer)/A67-0007/035.

${ }^{52}$ Falconer to H.H. Davis, 27 July 1916, UTA Office of the President (Falconer)/A67-0007/041.

${ }^{53}$ See for example, Joseph Banigan for the Delta Upsilon Fraternity Toronto Chapter War Committee to Falconer, 3 November 1917, UTA/Office of the President (Falconer)/A67-0007/046a.

${ }^{54} \mathrm{Mrs}$. Campbell was the widow of the late John Campbell, Professor at Montréal Presbyterian College. See UTA/Graduate Records/A73-0051/220/005(18)

${ }^{55}$ For evidence of this, see "Minutes of the House Committee, Queen's Hall 1911-1914," UTA/University College/A69-0011/022. Unfortunately no later minute books exist. 
constitution for the "Self-Government Association" of Queen's Hall, article 2, the Association was "to control all matters pertaining to the government of the Association in respect to Queen's Hall, subject to the approval of the [University College] Council." Although the Dean was notified of all meetings, she did not have a vote. Discipline was handled by the House Committee, and meted out by seniors and juniors only. The Dean handled only appeals of discipline cases. ${ }^{56}$

In the spring of 1914, a crisis involving dancing at Victoria College's Annesley Hall brought all residences under closer scrutiny. ${ }^{57}$ In March 1914, a female student was asked to leave Queen's Hall at the orders of Mrs. Campbell and of University Lady Superintendent Miss Salter. The Queen's Hall House Committee complained directly to the Caput (the central disciplinary body of the University) that the governance system at Queen's Hall was being overturned, and that the student in question had actually done nothing wrong. "Despite President Falconer's warning to the Varsity to keep quiet about 'the fuss at Queen's Hall', the news that something untoward had happened spread rapidly around the university," the Toronto World reported. ${ }^{58}$ The World noted two days later than despite all attempts by authorities to let the matter die down, ninety of the residents of Queen's Hall, "which means practically the entire list of students in the house," petitioned for reinstatement of the expelled student. ${ }^{59}$ As the Telegram reported that same day, there was a general feeling in the Hall that the discipline rules prevented them from attending University dances, and that many of the residents were considering leaving the Hall, replacing the Dean with a University graduate, or finding a new residence. ${ }^{60}$

Stung by complaints she was not maintaining a residence of high standards and culture ${ }^{61}$ and disconcerted by deputations of "young ladies" going over her head to University authorities without asking her to be present, Mrs. Campbell chose to resign, effective 1 September 1914. As Mossie Mae Kirkwood recalled years later, "There was this odd circumstance that Queen's Hall was regarded as rather, well... naughty, loose. And... it wasn't. ${ }^{32}$ Miss Alice Parkin, a former resident head at Upper Canada College, came from New York to take up the position. The

${ }^{56}$ "University College Queen's Hall Constitution for the Self-Government Association" (1914), UTA/Office of the President (Falconer)/A67-0007/056.

${ }^{57}$ McKillop, Matters of Mind, 251-2.

58 "Two Girls Gated One is Expelled," Toronto World, 7 March 1914, as clipped in UTA/Office of the RegistrarA73-0051/220/(18). Although the World suggests the Caput was consulted, there is no evidence to support this, and the Caput did not meet between 23 January and 19 September 1914, according to its own minutes preserved in UTA/Senate/A68-0012/reel 23.

${ }^{59}$ World, 9 March 1914, UTA/Office of the Registrar/A73-0051/220/(18).

${ }^{60}$ Telegram, 9 March 1914, UTA/Office of the Registrar/A73-0051/220/(18).

${ }^{61} \mathrm{Mrs}$. John Campbell to Falconer, 4 June 1914, UTA/Office of the President (Falconer)/A670007/027.

${ }^{62}$ Mossie May Kirkwood oral interview, 27 March 1973, UTA/B74-0020, 34. Kirkwood mistakes in this interview Mrs. Campbell and Louise Livingstone. Mrs. Campbell was not a university graduate and received criticism on this score. Livingstone was a graduate. 
Toronto Star heralded her appointment as a return to "a big new Alma Mater atmosphere" at the Hall.

As for the tangos, late hours, and general sensationalism of an unfortunate period of last year's term, [the Star continued] no laws are laid down at all... All the freshmen and all the men's years right up to the professors are going to know that Queen's Hall is alive. ${ }^{63}$

Certainly Parkin's initial moves were highly useful, assisting the House Committee to draft a new constitution for the Hall. As the Varsity noted in October 1914 , "It is hoped that this new constitution, coming as it does after two years of constant dissatisfaction will prove itself real self-government. ${ }^{\text {"64 }}$

Parkin resigned in June 1915 when she married Vincent Massey, leaving the position yet again vacant. This opened Queen's Hall to a serious political battle. The new Mrs. Massey attempted to name Margaret Wrong, daughter of Professor George Wrong of the University, as her successor with the backing of University College Council, who administered the affairs of the hall. ${ }^{65}$ This was opposed by the alumnae of the University, who wished to see a Toronto graduate take the position. (Wrong had attended, but not taken her degree at, Oxford.) As the World reported:

Miss Wrong is not old enough to hold a position such as head of the women's residence of the university, which they [the governors] are satisfied demands a woman with a wide range of experience who is considerably older than the girl students who come under her care. ${ }^{66}$

Her relation to Professor George Wrong became difficult, as many alumnae resented him for proposing a separate college for women in 1909.67

The Alumnae Association of University College presented Principal Maurice Hutton with a slate of possible graduates from University College, noting that "in filling positions of this kind special consideration should be given" to such gradu-

${ }^{63}$ Toronto Star, 1 October 1914, UTA/Office of the Registrar/A73-0051/220/(18).

${ }^{64}$ Varsity, 16 October 1914.

65 "Partial Memoirs of the Rev. D. Bruce Macdonald pertaining to the University of Toronto 1891-1945," UTA/B83-1295, 20-21.

${ }^{66}$ Toronto World,23 June 1915, UTA/Office of the Registrar/A73-0051/220/(18). On 10 June 1915, a suggestion was made to the Board of Governors that Miss Parkin carry on for a year without salary with Wrong serving under her. This was immediately referred to committee. The committee reported on 25 June, and the Chancellor, Sir William Meredith, immediately moved Livingstone be appointed and this was approved. See UTA/Board of Governors/A700024/reel 10. The bare-bones minutes neither confirm nor deny the World's story. D.B. Macdonald's memoirs contain certain factual errors and cannot be completely relied upon. $\mathrm{He}$ insists that the committee that recommended Livingstone consisted of him, Meredith, and Falconer, but Sir Edmund Walker's journals indicate that he participated in two meetings on the issue in Falconer's office. Both Walker and Macdonald independently confirm many of the elements of the story, especially those related to the involvement of women graduates.

${ }^{67}$ Sir Edmund Walker journal, 14 and 17 June 1915, Thomas Fisher Rare Book Library. As Walker put it on the 17th, "The name of Margery Wrong reached us with impossible surroundings and has not been discussed free from prejudice." 
ates. ${ }^{68}$ As the Secretary of the Alumnae Association wrote President Falconer, "No one can possibly so well understand their needs as College women, nor assist them so ably with her advice and guidance as one who has herself done the same work. ${ }^{199}$ The University Board of Governors appointed Miss Louise Livingstone, a graduate of 1894 on the Alumnae's list, to the Deanship. Hutton wrote Falconer, "I suppose the business is over although it illustrates again the difficulty of administering a University through laymen without academic interests." Hutton expressed his confidence in Livingstone as a "good woman," but noted ominously

I hope someday you will be able to get for the University the abilities and promise

of Miss Wrong. I have heard nothing from Mrs. Massey. She is perhaps rather annoyed. It cannot be helped. As also is Wrong. He will get over it. ${ }^{70}$

The Wrongs did not get over it, and Margaret became Resident Head of the Women's Union in the fall of 1916."

Creation of the position of Resident Head meant a direct conflict of authority between the two factions. The Resident Head was responsible for all women's activities at University College, and also was the guiding force behind the Women's' Undergraduate Association. While Livingstone was repairing the curtains at the Hall and firing a housekeeper she found "quite incapable" and lacking "correct training," and attempting to find a proper replacement, ${ }^{2}$ Margaret Wrong was creating a committee that would demand all fees for the support of the new Women's Union be collected at the Union itself, thus sapping money from Queen's $\mathrm{Hall} .{ }^{73}$ Wrong also recommended new regulations declaring all women not in residence in Queen's Hall be required to register with her at the beginning of term regarding their living arrangements, and that all women at University

\footnotetext{
${ }^{68}$ Executive of U.C.A.A to Hutton, 2 June 1915, UTA/Office of the President (Falconer) A67-0007/036.

${ }^{69}$ Oliver Ziegler to Falconer, 10 June 1915, UTA/Office of the President (Falconer)A670007/036. Ziegler was a graduate of 1914 and had been through the last days of Mrs. Campbell.

${ }^{70}$ Hutton to Falconer, 9 July 1915, UTA/Office of the President (Falconer)A67-0007/A67$0007 / 39$ a.

${ }^{71}$ The University College Alumnae Association met with Falconer on 8 April 1916 with the intention of submitting possible candidates for the position to him, but were told "he had decided on the nomination." The Alumnae Association pointed out that "the present names of appointment excluded from consideration many women of proved ability." They then drafted a letter to Falconer on 11 April setting out the qualifications which a Resident Head should possess, which were designed to exclude Wrong. See minutes of Alumnae Association, 20 April 1916, UTA/University College/A69-0011/016. The letter was read at the Board of Governors meeting on 13 April 1916, after which Falconer put forward Wrong's name for approval. The five Board members present approved the appointment without recorded dissent. See Minutes of the Board of Governors, UTA/Board of Governors/A70-0024/reel 10.

${ }^{72}$ This took over a year. See Livingstone to Falconer, 8 September 1915, 28 June 1916, UTA/Office of the President (Falconer)A67-0007/A67-0007/39a.

${ }^{73}$ "Club House" committee of University College women to Falconer, 4 October 1916, UTA/Office of the President (Falconer)A67-0007/A67-0007/45a.
} 
College have their registration cards stamped by her before being allowed to pay their fees. ${ }^{74}$ Wrong was trying to take over Queen's Hall indirectly.

Wrong also took steps to bring the sororities to heel. Sorority membership was sapping the cohesiveness of the student body in residence. Phyllis Grierson made this point to Sidney Smith in 1946, telling a story about herself and two other residents who joined sororities whereas Grierson did not.

Though we all three lived in residence, worked in the same labs, went to the same lectures, had our meals in the same hall at the same time there was no further contact between us for the last three years. ${ }^{75}$

As an individual I did not feel resentment because a sorority had not asked me....

But I could sense that those who did join had some control over those of their gang and over me and over everyone at that institution which I could not voice; a control which I did resent... If X did not want to know me she did not have to know me. If she did not want to live or work near me SHE could move. ${ }^{76}$

Although she would never have spoken of "gangs," Wrong understood the problem as well as Grierson. Wrong complained in 1917 that the initiation of first-year students outside Queen's Hall and of second year students within Queen's Hall "makes an unfortunate distinction between residence and nonresidence therefore it is suggested that the College Council pass a regulation enforcing 2nd year initiation for all the women in College." This would mandate students one year of student activity without division into secret societies. The sororities blocked this proposal for uniform rushing, over Wrong's serious protest. ${ }^{78}$ Wrong no doubt suspected the sort of suffering and exclusion which Grierson later declared. In 1920 Wrong reported regarding sororities, "Six are in existence now. I should like to ask that no new charters be granted without careful consideration." ${ }^{\text {79 }}$ Since sororities could not be brought to heel, and could not easily be disbanded, she wished their expansion checked before it was too late. By embarking on this course, she added sorority members to her list of enemies.

By 1919, University College women had reached levels of hopeless factionalization. The divisions between sorority and non-sorority students, Queen's Hall students and other students, Livingstone supporters and Wrong supporters, were being played out while the central administration of the University was preoccupied with other matters. Conditions worsened in the fall of 1919 when

\footnotetext{
${ }^{74}$ Report of the Dean of Women, 1917-18, UTA/University College Dean of Women/ B740011/01(07).

${ }^{75} \mathrm{Grierson}$ large document, 27. Grierson gives too few details here to confirm the identity of the two others, but at 39-41 she describes clearly another incident which no doubt refers to the sisters Mildred and Elsinore McPherson. The veracity of that later story convinces this author that she is not fabricating the first.

${ }^{76}$ Ibid., 28-9.

${ }^{77}$ Margaret Wrong's report to College Council, 2 March 1917, UTA/University College Dean of Women/B74-00011/01(07).

${ }^{77}$ Wrong to Hutton, 28 April 1917, UTA/University College Dean of Women/B74-00011/01(07).

TWomen's Union Annual Report, 1920, UTA/University College Dean of Women/B7400011/01(07).
} 
Hutton House was founded "in connection with the University College Women's Union" and under control of Wrong, without any self-goveming student body. ${ }^{80}$ As Mossie Kirkwood remembered,

It is an actual fact that the people at Hutton House... and the people at Queen's Hall hardly spoke to each other when they met in the park. There was such a strong antagonism between them. ${ }^{81}$

The antagonism flowed from a crisis that began in January 1919, when the Head Girl of Queen's Hall and the rest of the House Committee resigned because "the relative position of the Dean, the Head Girl, and the House Committee as elected by the Hall for self-government, have never been defined with sufficient clarity. ${ }^{m 2}$ Principal Hutton headed a committee to investigate the matter. It reported 18 February 1919 that Hutton insisted on revisions to the constitution of the self-government association. ${ }^{83}$ These transferred greater power to the Dean of the Hall, including power of expulsion and "immediate control" of Queen's Hall—but still allowed Hall matters to be administered "as far as possiblen by students. Further amendments to the regulations prohibited late leaves unless expressly permitted by the Dean. ${ }^{84}$ After being informed of these changes, the Hall mass meeting moved that Principal Hutton "remain and hear the students' discussion over the new measures." Instead Hutton abruptly left the meeting. Faced with an overruling of the self-government they held dear, the mass meeting moved to abolish its own association. "By this measure," The Varsity reported,

the students refuse to police themselves or act on a discipline committee to enforce laws which are not of their own legislation. The meeting decided that if the Council insisted upon passing rules obnoxious to the whole body of University women, they would have to enforce them themselves. ${ }^{85}$

Editorially, The Varsity put its finger on the problem:

With the outbreak of war and the necessity for both students and authorities to utilize every ounce of energy in the promotion of victory little chance was given for friendly intercourse and consequently the friendship bond was weakened. Although the relation between the students and the authorities was not strong, there was no absolute separation and there was a chance that this connection with the return of peace conditions might become closer. The sympathies of almost the entire student body are with the women residents. The consensus of opinion is, that if student government is abolished at Queen's Hall, Annesley Hall, Burwash Hall, the University College men's residences and other places where student

\footnotetext{
${ }^{80}$ Report of the Dean of Women 1920-1921, UTA/University College Dean of Women/ B74-0011/01(10).

${ }^{81}$ Kirkwood oral interview, 34.

${ }^{82}$ Varsity, 31 January 1919.

${ }^{83}$ Ibid., 21 February 1919.

${ }^{84}$ See revisions to constitution and statement "University College: Queen's Hall” in UTA/Office of the President (Falconer)A67-0007/A67-0007/056.

${ }^{85}$ Varsity, 21 February 1919.
} 
government is now in power will soon come under the sovereignty of an aristocratic government. ${ }^{86}$

On 12 March 1919, thirty-two fourth-year students at Queen's Hall sent a petition to President Falconer demanding he intervene in the affair, claiming the situation at Queen's Hall had been altered without the consent of the residents, and asking that "some women graduates who have experienced residence life be

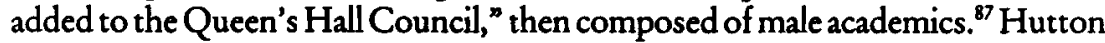
drafted a reply, never sent:

You appear to request that the buildings be handed over to the students... The public opinion of this Province and of your parents will demand emphatically that the precautions taken for the safeguarding of women students be far more careful than casual... I suggest you enlighten yourself on this matter. ${ }^{88}$

Hutton was not alone in making this suggestion. A letter from a University "Women's Committee" of all the deans of residence had approached Falconer in February 1919, asking for greater University efforts to limit student late-night activities, and to "discourage the attendance of University students at dance halls and down-town restaurants after evening gatherings. ${ }^{\text {"89 }}$ In preferring a lessfavoured definition of "self-government," the Queen's Hall students positioned themselves on the wrong side of administrative politics. ${ }^{90}$

Under Hutton's direction, University College Council decided to appoint a new committee to investigate the situation at Queen's Hall. After a mass meeting of students on 28 April 1919, the committee reported the difficulty at the hall "lay primarily in incompatibility between the Dean and the House Committee and the desire of the students to have the right of making and administering their own rules." Professor Wallace called for the resignation of the Dean. ${ }^{91}$ On 3 May the Council made this official, saying that the position of Dean of Queen's Hall "should be an academic appointment... in the hands of the President" and that "the only solution of such difficulties presumably lies in the resignation of the Dean." University, which did not act upon them because of a deadlock in opinion.

${ }^{86}$ Ibid., 24 February 1919.

${ }^{87}$ Queen's Hall Fourth Year to Falconer, 12 March 1919, UTA/Office of the President (Falconer)/A67-0007/054.

${ }^{88}$ Undated and unsigned letter in UTA/Office of the President (Falconer)/A67-0007/054. The handwriting appears to be Hutton's.

${ }^{89}$ Margaret Addison to Falconer, 1 February 1919, UTA/Office of the President (Falconer)/ A67-0007/051a.

${ }^{90}$ In 1919 "self-government" had two recognized meanings. The first and earliest, "selfcontrol" or "self-command," is now considered rare. The second meaning, "administration of affairs without external direction or interference" has become the more common meaning. In 1919 , however, a "self-government association" was a double-entendre similar to that of "responsible government." See The Oxford English Dictionary, second edition.

${ }^{91}$ Minutes of a Special Meeting of College Council, 1 May 1919, UTA/University College Council/A69-0016.

${ }^{92}$ Minutes of a Special Meeting of College Council, 3 May 1919, UTA/University College Council/A69-0016. 
After meeting with Livingstone and studying the situation, two members of the Board's committee concurred with the Council of University College, while the other two members wished for a new committee "to make a thorough investigation of all the issues that have been raised in connection with Queen's Hall." ${ }^{93}$ The College Council was unwilling to wait. On 3 October 1919 it informed the Board of Governors "that under existing conditions it is impossible for them to administer Queen's Hall satisfactorily," and that they no longer held "themselves responsible for the discipline or management of Queen's Hall." "94 They reiterated this in 1920 when the Board of Governors suggested transferring control of the hall to an advisory committee of women. College Council replied:

The Governors by this proposal show the same lack of confidence in the Council as they did a year ago; and under such conditions the Council cannot see its way to resuming jurisdiction of the Hall. ${ }^{95}$

For the remainder of its existence, Queen's Hall became a University residence, not affiliated with a College.

University College took extreme steps to make the breach complete. Not only was Hutton House created, but another residence, Argyll House, was founded by a concerned group of ladies, under the direction of May Pitkin Wallace, wife of Professor Wallace. ${ }^{96}$ In a letter to President Falconer in the fall of 1918, Wallace spoke of "the unusual difficulty in finding suitable rooms for University girls this year," a veiled reference to the suitability of Queen's Hall." Margaret Wrong and her successors struggled to stop the University Calendar from listing the Hall as a College residence. ${ }^{98}$

Wrong influenced the WUA to amend its constitution to remove the Head Girl of Queen's Hall from her position on the executive, on the basis that the Hall was no longer a University College residence, and certainly not the only residence at which U.C. students were located. The circumstances of Queen's Hall were deflecting attention from the general battle of the WUA for more residence space for students. This amendment met with strenuous objection from Queen's Hall students present at the meeting en masse. "Queen's Hall contended that while technically it is not a U.C. residence, in reality it is, as none

${ }^{93}$ Minutes of the Board of Governors, 10 July 10,1919, UTABBoard of Governors/A70-0024/010.

${ }^{94}$ Minutes of College Council, 3 October 1919, UTA/University College Council/A69-0016.

${ }_{95}$ "Resolution passed unanimously by the Council of University College, 17 May 1920, UTA/University College Council/A69-0016.

${ }^{96}$ Varsity, 2 October 1918. Later accounts insist that it was Margaret Wrong who was most responsible for securing the house, see Varsity, 2 October 1930. Argyll house was the former home of the Campbell family, who sold the house to the University on the provision that half of the thirty-one residents be female medical students.

${ }^{97}$ Wallace to Falconer, 8 October 1918, UTA/Office of the President (Falconer)A67-0007/055. The total enrolment of women at University College in $1917 / 18$ was 376 and in $1918 / 19$ had risen only to 400 . Increased numbers could not have created the "unusual difficulty."

"See Reports of the Dean of Women, 1919-20, 1921-22, UTA/B74-0011.Margaret Wrong left the University in the summer of 1921 to take up the position of world secretary of the Students' Christian Federation. See UTA/Graduate Records/"Margaret Christian Wrong"/A73-0026/529(02). Livingstone stayed. 
but U.C. girls are in residence there." A motion on the amendment tied 103-103 on a secret ballot, and was defeated.9

The next day, the entire WUA executive and its Honourary President resigned in protest, claiming "that the constitution has been imperiled, if it has not completely broken down." Miss Bott, the Honourary President, stated that

[d] espite repeated efforts on the part of supporters of the amendment to keep the discussion to the main issue, the principle of residence representation, the opposition tended to lose this impartial note and become bitter and personal in tone. Criticisms passed on certain of the residences were unprovoked, unwarranted, and irrelevant. ${ }^{100}$

The Varsity commented that "Such continual bickering only fritters away valuable energy which is much needed for things of more importance." ${ }^{\text {101 }}$ It also dissipated respect for women's responsibility and decorum in student activities built up over the years.

The general nastiness of the WUA mass meeting increased fears of a moral collapse among female students at University College. Grierson had already noted that among her 1917 undergraduate colleagues were

a few who want extra favors, extra privileges, extra power of government over others-power to bully, exploit, interfere with, subject, irresponsibly judge, control, and govern others to serve their underhand, sneaking selfish interests and desires. ${ }^{102}$

Meanwhile "many... attractive, well-bred, well-mannered girls" were excluded from influence. "None," she insisted, "seemed to even sense the great moral, Christian issue involved in the legalization of such subjection and exploitation of the individual student." ${ }^{103}$

This may have been true in 1917 , but by 1921 , after the war, these same questions came back to the surface of University life. In a submission to the Royal Commission on University Finances in 1921, the University College Alumnae Association noted that rooming houses were causing "moral problems" and that in general, "even for women in residence the conditions are highly unfavourable to their proper development for going out through the Province to help shape its future." ${ }^{104}$ This followed upon the recommendation of the female graduate members of the Committee on New Buildings for Women in University College that "there is need of more effective control of all the women of the College."105

\footnotetext{
${ }^{99}$ Varsity, 18 February 1920 . The WUA constitution required a two-thirds majority to pass amendments.

${ }^{100}$ Ibid., 20 February 1920.

${ }^{101}$ Ibid., 25 February 1920.

${ }^{102}$ Grierson smaller document, 2.

${ }^{103}$ Ibid., 5, 9.

${ }^{104}$ Alumnae Association of University College submission in H.J. Cody, ed., Report of the Royal Commission on University Finances (1921), 78-9.

${ }^{105 \alpha}$ Memorandum from the Committee on New Buildings for Women in University College", UTA/Office of the President (Falconer)/A67-0007/056.
} 
The question was not just the moral failure demonstrated by back-biting in College halls and at University meetings. There were objections to unseemly activity by University College women-for example, those expressed by the chief librarian of the Public Library of Toronto, George H. Locke, who wrote George Wrong in March 1918 and copied his letter to the President:

We have tried in every way to make ourselves useful... but they [students] have abused our hospitality by writing notes on the margins of our books, by underlining words, and making it necessary for us to clean our books from time to time. This applies particularly to translations of Goethe and Schiller which the students use for 'ponies' I suppose.

Defacement was not the only problem:

The students take away books from time to time... and our list of lost books this year was made up to a great extent of books which were on the University course of reading.

Locke continued,

I regret to say that very many of these offences are committed by girls, and there seems to be a feeling among the girls that we exist merely for their convenience, and a disinclination to help us and keep the Library useful to the public. I have noticed this sometimes in the disregard of the simple rules we have, and a disposition to assert an unpleasant proprietorship and even condescension. ${ }^{106}$

In two pages Locke managed to accuse the women of U.C. of being thieves, cheaters, and generally rude. Falconer responded by saying he would place a notice in the women's reading rooms, and told Locke:

If we receive from you further reports as to such conduct we would advise you to close the use of the Library against our students. This seems to me pretty drastic, but apparently some need a harsh lesson. ${ }^{107}$

Falconer waited until after the war to drive the harsh lesson home. Margaret Ross was expelled from the University for "moral failure." The charge stemmed from the disappearance of a fur coat, taken from the cloak-room of the Chemistry building on 3 April 1919. On 4 April 1919, at the request of President Falconer, the Pinkerton Detective Agency was hired to track down the coat, the property of a Miss Bernice Johnston of the Faculty of Medicine. ${ }^{108}$ After following several leads into seamy back alleys in downtown Toronto, the Pinkerton's concentrated their investigations on the University of Toronto campus.

On 11 May 1919, Detective Hammond followed up "some talk" among the girls of the residence at 184 College Street, where "just recently there had been some more thefts of money." The talk revolved around Ross, "said to have possession of a fur coat, around which there seems to be a little mystery as to how she came to have it. ${ }^{109}$ Ross told several stories about the coat over a course of interviews, claiming it had been bought by her father, found at a theatre, and, finally, bought from another girl whom she was trying to protect. The fact

\footnotetext{
${ }^{106}$ Locke to Wrong, 11 March 1918, UTA/Office of the President (Falconer)/A67-0007/48a.

${ }^{107}$ Falconer to Locke, 13 March 1918, UTA/Office of the President (Falconer)/A67-0007/48a.

${ }^{108}$ Graham Campbell to Falconer, 21 May 1919, UTA/Office of the President (Falconer)/A670007/58b.

${ }^{109}$ Pinkerton report, 11 May 1919, UTA/Office of the President (Falconer)/A67-0007/62.
} 
remained that Ross had taken it to be altered at Holt Renfrew the day after it disappeared from the Chemistry building. Ross was suspected of other thefts at 184 College Street and at Queen's Hall the year she stayed there. ${ }^{110}$

Ross stuck to her final story. She had purchased the coat from another girl who she could now not positively identify. Interviews with other residents at 184 College Street turned up the evidence that many of the girls talked about Ross, "and while they did not directly accuse her of certain thefts that had occurred around the building, they practically hinted at such. ${ }^{111}$ Her father was called in from Brucefield, Ontario. He denied buying the coat, and Margaret reverted to her story about finding it in a theatre. As the Superintendent reported,

I cannot help but feel, in view of the contradictory stories given by Miss Ross ... that her explanation in regard to the fur coat cannot be accepted as being very satisfactory. ${ }^{112}$

Falconer agreed, and Margaret Reinke Ross was bounced from the university, her third year exam results annulled. ${ }^{113}$ After some confusion with the mail, her father paid Bernice Johnston to replace the coat. ${ }^{114}$

Mrs. Ross would not be satisfied. On 4 September 1919 she wrote Falconer to protest removal of Margaret's name from the roll of students at the University.

I sent the girl there with the understanding that she would be taken care of by the dean of the boarding house... I have spent $\$ 1000$ during the three years there and I want to know what she is going to do for me.... I never got any word about the conduct of the house or she would certainly kept away. I have never heard her 3rd year results. I paid good money for the exams and I want to hear the results. Margaret denies ever stealing the coat and because she cannot find the other party the blame should be laid on her. What about the articles she had stolen why don't you banish those girls, just because Margaret did not make a noise about it. They did not get-it. Margaret was held in the very highest esteem until she went to Toronto and those foolish headed girls that you have attending the University know nothing but pride and society that will never take them to Heaven. Now I want to know if you can get her a position to earn the money she has spent. Margaret was very clever at Collegiate that is [why she?] was advised to advance her studies. She was talked of by everybody as being the most sensible and clever girl in these parts and this has put a blanket on the University in these parts. Hoping you will see your way clear to answer this letter and give me some incouragement [sic] and ask the dean of the house also what she will do to clear herself, Yours, Mrs D.M. Ross. ${ }^{115}$

Falconer replied:

Her guilt was so manifest that there was no other course... If the matter had been laid before outside authorities it might have proved to be even more serious that

\footnotetext{
${ }^{110}$ Pinkerton report, 12 May 1919, Ibid.

"11Pinkerton report, 16 May 1919, Ibid.

${ }^{112}$ Campbell to Falconer, 21 May 1919, UTA/Office of the President (Falconer)/ A67-0007/62.

${ }^{113}$ Caput minutes, 29 May 1919, UTA/Senate/A68-0012/reel 23.

${ }^{14}$ See Johnston to Falconer, 25 June and 28 July 28, 1919, UTA/A67-0007/58b; Donald Ross to Falconer, 1 July 1919, UTA/Office of the President (Falconer)/A67-0007/60a.

${ }^{115}$ Mrs. D.M. Ross to Falconer, 4 September 1919, UTA/Office of the President (Falconer)/A67-
} $0007 / 60$. 
it was but our whole desire was to protect your daughter as far as possible while at the same time doing justice within the University itself.

Her guilt has been so thoroughly proved that instead of writing to me in complaint because she did not receive the protection that you think was due to her from the Dean of Residence I think you should have expressed some regret for her wrong-doing. ${ }^{116}$

This letter closed the books on the Ross case. ${ }^{117}$

No attempt was made to investigate wrong-doing by any other "girls." Margaret crossed the border into the United States and died in Detroit in 1920. ${ }^{118}$

Ross was the only woman so treated by the University authorities, although her insistence that there were other thieves and rogues in the residences at the University is supported by Phyllis Grierson's testimony. Grierson may have been mad, but Ross was not. She was respected enough by her fellow students to be elected to the executive of the WUA. But she had lived in Queen's Hall and was not a sorority girl. Does this mean she was set up as a fall-girl by the other residents of the Hall? Was she goaded into stealing the coat, or did she in fact purchase it from another girl who had stolen it, and then realize that as an outsider she could never prove her case? The Pinkerton investigation paints her as a pathological liar, but this could have been the result of confusion over being accused of a crime for which other girls routinely went unpunished. As Grierson put it:

It was not pleasant to be made to appear as a girl whom it was not quite nice or safe to know, a girl who must surely have something wrong with her. At that cess-pool, that stink-pot of legalized underworld social politics, filth and racketeering, it was neither safe nor profitable to be too polite to the wrong person. ${ }^{119}$

Ross may have committed the same sin, or perhaps just been on the wrong side of the war years.

After the First World War authority in women's residences was shored up at University College. New residences were run more expressly in locoparentis than they had during the War. They were designed to be "centres of home-like influence ${ }^{120}$ with high academic standards and a moral tone above reproach. The proper role of university women would be debated endlessly by students, administrators, and the general public in the $1920 \mathrm{~s}$ in Toronto and elsewhere, ${ }^{121}$ but at no point would the entire administrative structure of women's activities be so paralyzed and split into factions as between 1910 and 1921. Indeed, by the 1930s, when both Queen's Hall and Argyll House were shut down, a new process of

${ }^{116}$ Falconer to Mrs. Ross, 6September 1919, UTA Office of the President (Falconer)/ A67$0007 / 60$ a.

117Falconer reported to the Caput on 11 October 1919 that "the matter had been settled." UTA/Senate/A68-0012/reel 23.

${ }^{118}$ Or so it appears from Alumni records, UTA/Department of Graduate Records/ A87-0045.

${ }^{119}$ Grierson large document, 21.

${ }^{120}$ See Alyson E. King, "Centres of 'Home-Like Influence': Residences for Women at the University of Toronto," Material History Review 49 (Spring 1999): 39-59.

${ }^{12 !}$ McKillop, Matters of Mind, 414-20. Discussions were most intense in the United States: see Nancy F. Cott, The Grounding of Modem Feminism (New Haven: Yale University Press, 1987), 148-62. 